УДК 94(437.1) “1268/1270”

DOI: $10.24144 / 2218-5348.2019 .1-2(19-20) .132-145$

Ліхтей Ігор,

кандидат історичних наук, доцент, завідувач кафедри античності, середньовіччя та історії України домодерної доби ДВНЗ «Ужсгородський національний університет»

\title{
УТВЕРДЖЕННЯ ВЛАДИ ЧЕСЬКОГО КОРОЛЯ ПРШЕМИСЛА ОТАКАРА ІІ В КАРИНТІЇ І КРАЙНІ (1268 - 1270 рp.)
}

У статті висвітлено процес утвердження влади чеського короля Пршемисла Отакара II в Каринтії та Крайні.У 976 р. Каринтія стала гериогством, володарі якого на перших порах часто змінювалися. У 1077 р. спадковими правителями гериогства Каринтії стала родина Еппенштейнів. Однак у 1122 р. ия родина вимерла, $i$ до влади в Каринтії прийшли Шпангайми. У січні 1256 р. помер Каринтійський герияог Бернгард II Шпангаймський, і владу перебрав його первісток Ульріх III. На той час він уже був гериогом Крайни, владу над якою отримав завдяки шлюбу з єдиною спадкоємицею иъього територіального князівства. Гериог Ульріх ІІІ Шпангаймський перебував у родинних зв'язках із чеським королем Пршемислом Отакаром II, доводився йому кузеном.У 1268 р. Ульріх III заповів свої володіння Пршемислові Отакарові II й таким чином позбавив права на їх успадкування свого молодшого брата Філіпnа. Наступного року Ульріх III помер, $і$ Філіпп висунув свої претензї̈ на спадщину брата. У изьому його підтримав угорський король Іитван V. Натомість Приемисл Отакар II уклав із Іштваном V перемир'я й наприкіниі 1270 р. утвердив своє панування в Каринтії та Крайні.

Ключові слова: Пршемисл Отакар II, Ульріх III Шпангаймський, Філіпп Шпангаймський, Іитван $V$, Чеське королівство, герияогство Каринтія, гериогство Крайна, Зальибурзьке архієпископство, Аквілейський nampiapxam.

The article I.Likhtei covers the process of power strengthening of the Czech king Przemysl Ottakar II in Carinthia and Kraina. In 976 Carinthia became a duchy, whose rulers often changed at first. In 1077the family of Eppenstein became the hereditary ruler of the duchy of Carinthia. However, in 1122 the family became extinct and the Shpangeims came to power in Carinthia. In January 1256 Carinthian duke Bernhard II of Shpangeim died and his firstborn son Ulrich III took the power. By that time, he was already the Duke of Kraina, over which he gained the power through marriage to the sole heir of that territorial principality. 
The Duke Ulrich III of Shpangeim was in a family relationship with the Czech King Przemysl Otakar II, they were cousins. In 1268 Ulrich III bequeathed his possessions to Przemysl Ottakar II and thus deprived the rights of their inheritance by his younger brother Philip. Next year Ulrich III died and Phillip made his claim to his brother's inheritance.He was supported by the Hungarian king Istvan $V$. However, Przemysl Ottakar II did not give up - he made a truce with Istvan V and at the end of 1270 confirmed his domination in Carinthia and Kraina.

Keywords: Przemysl Ottakar II, Ulrich III of Shpangeim, Philip of Shpangeim, Istvan V,the Czech Kingdom, the Duchy of Carinthia, the Duchy of Kraina, the Archbishopric of Salzburg, the Aquileian Patriarchate.

Постановка проблеми. В середині XIII ст. Чеське королівство стало відігравати більш вагому роль у суспільно-політичному житті Центральної Європи. Авторитет і могутність країни особливо зросли за правління Пршемисла Отакара II (1253 - 1278). В умовах послаблення Священної Римської імперії цей чеський володар намагався активно реалізувати ідею утворення універсальної монархії, яка мала об'єднати під його скіпетром території деяких сусідніх держав.

У 1253 р. після смерті свого батька Вацлава I (1230 - 1253) Пршемисл Отакар II став повновладним чеським володарем.На той момент ситуація у Священній Римській імперії була неспокійною. Серйозну небезпеку для іiі правителя Конрада IV (1250 - 1254), сина і спадкоємця імператора Фрідріха II Штауфена, становив антикороль Вільгельм Голландський $(1247$ - 1256). Його було обрано ще в 1247 р. частиною знаті, опозиційно налаштованої до Штауфенів. Щоправда, Вільгельм не мав авторитету серед німецьких князів, його владу визнавали лише частково, переважно в регіоні нижнього Рейну. Після того, як 21 травня 1254 р. у військовому таборі біля поселення Лавелло (південь Італії) Конрад IV помер, в історії імперії настав період міжкоролів'я (interregnum, 1254 - 1273). На той час єдиний син покійного, теж Конрад, який прописався в історії за італійською зменшувальною формою свого імені як Конрадін, не мав ще й двох років. Він народився у шлюбі Конрада IV 3 Єлизаветою фон Віттельсбах, донькою рейнського пфальцграфа i баварського герцога Оттона II Ясновельможного(1214 - 1253) 3 династії Віттельсбахів. Саме під його опікою і знаходився Конрадін.

Наприкінці листопада 1253 р. Оттон II Ясновельможний помер, i влада перейшла до його сина Людвига II Віттельсбаха (1253 - 1294), при дворі якого надалі виховувався й Конрадін. У 1255 р. спадщину Оттона II Ясновельможного було поділено між Людвигом II та його братом Генріхом XIII. В результаті, Людвиг II Віттельсбах зберіг владу над Верхньою Баварією і пфальцграфством Рейнським. Решта ж території герцогства, точніше Нижня Баварія, перейшла під владу Генріха XIII Віттельсбаха (1255 
- 1290). Щоправда, обидва брати послуговувалися герцогським титулом [7, c. $150 ; 10$, p.388 - 389].

Попри те що Конрадін був ще дитям, він отримав титул герцога Швабії й претендував на королівський трон Сицилії та Єрусалима. Успадкуванню Конрадіном німецького трону протидіяла папська курія [2, с.339 - 340; 3, с 195 - 196, 213 - 214; 5, с.208]. Після смерті 1256 р. Вільгельма Голландського відбулися нові вибори. В результаті у 1257 р. на німецькому троні знову опинилося двоє володарів - Річард X Корнуельський (1257 - 1272), рідний брат англійського правителя Генріха III, і Альфонс X Кастильський (1257 - 1274), онук короля Філіппа Швабського (1198 - 1208), дядька Фрідріха II Штауфена [1, с.60 - 61, 2, с.339 - 340, 372; 5, с.208 - 212].

3 обома німецькими королями Пршемисл Отакар II підтримував добрі стосунки і з їх мовчазної згоди утверджував своє панування в альпійському регіоні. Ще наприкінці1251 року, після того, як у Австрійському герцогстві вимерла чоловіча частина династії Бабенбергів, Пршемислові Отакарові II вдалося здобути це осиротіле територіальне князівство. Своє панування в Австрійському герцогстві він легітимізував завдяки шлюбу (укладеному заднім числом) 3 останньою представницею династії Бабенбергів Маргаритою. В ході протиборства 3 угорським королем Белою IV (1235 1270) чеський правитель підкорив також герцогство Штирію (1261). У 1265 p. Річард Корнуельський призначив Пршемисла Отакара II захисником імперського маєтку на правобережжі Рейну. Чеський король використав свою нову посаду та приєднав до своїх володінь Егерський край, тобто регіон у чесько-німецькому прикордонні 3 центром у м.Егер (нині - місто Хеб у Чеській Республіці - І.Л.). Такі дії Пршемисла Отакара II спричинили війну 3 баварськими герцогами Віттельсбахами, яка закінчилася в 1267 p. компромісним примиренням $[6$, c. $67-72 ; 20$, s. 3 - 150; 22, 223 - 227; 25, s. 15 - 41, 26, s.97 - 130]. Відтак у сфері інтересів Пршемисла Отакара II опинилася Каринтія і Крайна.

Мета дослідження. Позаяк дискусійні питання утвердження влади Пршемисла Отакара II в герцогствах Каринтії і Крайні ще не були предметом докладного вивчення в українській історичній славістиці, то пропонована студія є спробою заповнити ще одну лакуну минулого Чеської держави.

Джерельною основою для підготовки статті послужили передусім аннали й хроніки, написані в тих чи інших регіонах сучасних Австрії й Німеччини, а також матеріали чеського, угорського та австрофрейзінгенського дипломатарію. На особливу увагу заслуговує текст Подєбрадської угоди 1268 року.

Результати дослідження. У 976 р. Каринтія стала герцогством, володарі якого на перших порах часто змінювалися. У 1077 р. спадковими правителями герцогства Каринтії стала родина Еппенштейнів. Однак у 
1122 р. ця родина вимерла, і до влади в Каринтії прийшли Шпангайми, які володарювали тут до 1269 р.[4, s.35].

Важливу роль у житті Каринтії відігравало Зальцбурзьке архієпископство, яке було засноване ще у VIII ст.У 1246 р. архієпископом Зальцбурга було обрано Філіппа з роду Шпангаймів (пом.1279 р.). Він був сином каринтійського герцога Бернгарда II та Юдіти, сестри чеського короля Вацлава I, тобто кузеном Пршемисла Отакара II.

Слід відзначити, що Філіпп та його старший брат Ульріх III 3 дитинства були тісно пов'язані з королівською родиною у Празі. Близько 1237 р. Вацлав I призначив Ульріха управителем Вроцлава. Натомість Філіпп, якому було уготовано церковну кар'єру, у 1239-1240 роках став пробстом Вишеградського капітулу і на деякий час королівським канцлером. Та попри це, він виношував плани щодо отримання після смерті батька Каринтії. Аби зберегти спадкові права на Каринтійське герцогство, Філіпп навіть ухилився від висвячення в духовний сан і управляв Зальцбурзьким архієпископством як “обраний архієпископ” [8, с.110; 20, s.69 - 70; 26, s.106].

Заповзятий та не позбавлений військового хисту, Філіпп досить швидко не лише зміцнив своє становище, але й суттєво розширив володіння архієпископства. У січні 1256 р. помер Каринтійський герцог Бернгард II, i владу перебрав його первісток Ульріх III, тобто старший брат Філіппа Шпангаймського. Ще в 1248 р. Ульріх III, завдяки шлюбу з Агнесою фон Андекс-Меран (пом. 1260 р.), яка була спадкоємицею Крайни, отримав у володіння й це герцогство.

Новий герцог, як і його батько, й надалі підтримував дружні стосунки 3 празьким керманичем, а в його канцелярії трудилися міністеріали чеського походження, які вдосконалювали свій фах ще за Бернгарда II. Взаємною прихильністю 3 Пршемислом Отакаром II був пов'язаний i Філіпп Шпангаймський, який не полишав намірів стати герцогом Каринтії. Однак Пршемисл Отакар II прагнув, аби Філіпп Шпангаймський якомога довше залишався на архієпископському престолі в Зальцбурзі, адже через нього чеський король мав можливість тримати під контролем баварські справи. Задля цього Пршемисл Отакар II матеріально підтримував свого кузена.

Втім, становище Філіппа Шпангаймського дедалі ускладнювалося. Поки папою був Іннокентій IV (1243 - 1254), він мав певний захист. Та його наступник, папа Олександр IV (1254 - 1261), не мав наміру задовільняти самолюбство Філіппа Шпангаймського. Врешті-решт витівки архієпископа Зальцбурга, його світський спосіб життя й суперечки з капітулом настільки обурили Олександра IV, що той не стримався й відкрив на нього карну справу [20, s.70; 26, s.106, 140].

Неспокійно було і в Зальцбурзькому архієпископстві. Так, "Гарстенські аннали" повідомляють, що в 1256 р. "Філіпп, архієпископ Зальцбурга, після багатьох турнірів, нестерпних для його церкви, які він 
урочисто провів у Мюльдорфі, зазнав нападок з боку своїх міністеріалів і каноніків, позаяк багато хто сумнівався, наскільки він відповідає [сану] єпископа"[14, р.600].Того ж таки 1256 р. частина зальцбурзьких каноніків позбавила Філіппа архієпископства й обрала своїм новим пастирем єпископа Зеккау - Ульріха фон Кірхберга, який колись був протонотаріусом канцелярії Бабенбергів. Його активно підтримував баварський герцог Генріх XIII Віттельсбах.

Однак Філіпп не надто зважав на Генріха XIII Віттельсбаха і на бажав поступатися архієпископським престолом на користь Ульріха фон Кірхберга. За допомогою чеського правителя Філіпп зумів утримати свою перевагу і на початках успішно боронив власні інтереси у папській курії. Ситуація в Зальцбузі ставала дедалі більш напруженою. I хоча 1258 р. Ульріха фон Кірхберга було затверджено в Римі й відбулося його висвячення в сан (за умови виплати в папську скарбницю 4 тис. марок сріблом), - Філіпп не здавався. Довідавшись про те, що його позбавлено архієпископської кафедри, він став злісно виступати проти каноніків та міністеріалів, плюндрував і спопеляв їхні землі, грабував і підпалював церковні маєтки. В результаті Ульріх фон Кірхберг так і не зумів утвердитися в Зальцбурзі і був архієпископом радше титулярним, ніж фактичним.

Герцог Ульріх III підтримував близькі стосунки із чеською королівською родиною і був відданим союзником Пршемисла Отакара II. Він діяв на боці чеського короля не лише під час суперечки через Зальцбурзьке архієпископство, владу над яким не зміг утримати молодший брат герцога Філіпп, але i в подальшому служив йому вірою та правдою, надаючи допомогу в інших справах. Щоправда, Ульріх III не мав спадкоємців, тож для Пршемисла Отакара II майбутня доля Каринтії була стратегічно важливою. Як відомо, Ульріхів брат Філіпп вже давно виношував плани стати герцогом Каринтії. Однак, на думку чеського дослідника В.Ванічека, його кандидатура, мабуть, була неприйнятною ні для Пршемисла Отакара II, ні для частини населення Каринтії. Для чеського короля було важливо взяти під свій безпосередній контроль Каринтію й пов’язану з нею Крайну. Задля реалізації своїх намірів він, за влучним висловом В.Ванічека, обрав шлях регіонального консенсусу [24, s.124].

На початку грудня 1268 р. Пршемисл Отакар II запросив до Чехії герцога Ульріха III та двох графів з альпійського прикордоння - Альберта II Гройче-Тирольського й Ульріха фон Гайнбурга. Відтак 4 грудня 1268 р. всі вони зустрілися в Подєбрадах, де герцог Ульріх III уклав із Пршемислом Отакаром II угоду щодо успадкування Каринтії. У грамоті, виданій з цього приводу, Ульріх III акцентує увагу на своїй бездітності, на добрих родинних взаєминах із Пршемислом Отакаром II, який неодноразово проявляв до нього щиру любов, а тому в разі смерті всі його землі, маєтки і ленні території повинні відійти до чеського короля. На зустрічів Подєбрадах були також 
присутні вишеградський пробст і канцлер Чеського королівства магістр Петрта брненський пробст Конрад [13, num.573, p.152 - 154].

Отже, Пршемисл Отакар II став спадкоємцем володінь свого племінника, хоча безпосередньо про Каринтію як імперське герцогство при цьому навіть не згадувалося, тобто угода містила непевне означення того, що саме Ульріх III заповідав.До того ж, призначення на посаду в імперському герцогстві належало до компетенції німецького короля. На думку Йозефа Жемлічки, той факт, що в підписаній у Подєбрадах угоді не йдеться про "ducatus" чи "principatus" (саме така назва мала б вживатися при означенні герцогства), а мовиться про анонімні землі, маєтки й ленні володіня, є свідченнямтогочасних реалій в цьому регіоні.Герцогська влада на території Каринтії, а також пов'язаної з нею Крайни, де Шпангайми утвердили своє панування завдяки першому шлюбу Ульріха III з Агнесою фон АндексМеран, була зруйнована претензіями 3 боку впливових родів і великих церковних ленів (Зальцбурга, Гурка, Бамберга, Аквілеї та ін.).

3 Подєбрадського акта, як слушно наголошує далі Й.Жемлічка, зиск отримав лише чеський король, тоді як Філіпп Шпангаймський опинився на лаві запасних. Тож немає жодного сумніву в тому, що саме Пршемисл Отакар II був зацікавлений у появі цього документа. Водночас угода мала стати запобіжним кроком у разі висунення претензій на спадщину Ульріхової другої дружини Агнеси, доньки Гертруди Бабенберг [26, s.140].

Отже, підписанням угоди в Подєбрадах герцог Ульріх III, у володінні якого перебували світські маєтки роду Шпангаймів, позбавив спадку свого брата Філіппа. Втім, невдовзі для Філіппа несподівано з'явилася можливість отримати престижний і фінансово привабливий церковний бенефіцій. Так, 8 вересня 1269 р. в Чівідале помер Аквілейський патріарх Грегоріо ді Монтелонго (1251 - 1269), який був першим італійцем на цьому давньому престолі. Це сталося під час повторного нападу на землі Аквілеї графа Альберта II Гройче-Тирольського. В умовах серйозної загрозизібрання станів Фріуля 14 вересня 1269 р., тобто вже через тиждень після смерті Грегоріо ді Монтелонго, обрало Ульріха III капітаном і управителем патріархату. Однак Ульріх III дав чітко зрозуміти фріульцям, що господарем ситуації є чеський король. Водночас йому здалося, що брат Філіпп може отримати відшкодування за втрату спадщини через угоду в Подєбрадах, якщо отримає сан патріарха Аквілеї. Такому, не надто приємному, рішенню Аквілея скорилася, й 23 вересня 1269 р. Філіппа, який так і не мав священницького сану, обрали патріархом [23, s.131 - 143, 25, s.124 - 125].

Однак уже 27 жовтня 1269 р. Ульріх III помер. Утративши відданого союзника, Пршемисл Отакар II відрядив до Каринтії брненського пробста Конрада. Як свідок укладення угоди в Подєбрадах він повинен був перебрати під чеську владу замки каринтійської знаті та герцогський маєток. На цей раз активність чеського короля наразилася на несподівану перешкоду: на опір 
аквілейського електа Філіппа, який переоцінив власні шанси й 2 листопада 1269 року в Любляні (Крайна) назвався законним спадкоємцем і принцепсом землі (verushereset princepsterre). Щоправда, спочатку він не надто афішував свої справжні наміри. Несподівано Пршемисла Отакара II також зрадив пробст Конрад, який був готовий підтримати виступ Філіппа фальшивим свідченням про зібрання в Подєбрадах. Підсилити претензії Філіппа мала підроблена задля цього грамота короля Вільгельма Голландського, згідно 3 якою Каринтію як імперське лено нібито було передано братам Ульріхові й Філіппові у спільне управління $[9$, p.798; 17, p.651; 19 , num. 1, p. $1 ; 21$, s.65 66; 24, 125].Однак Пршемисл Отакар II не бажав відмовлятися від своїх намірів і вже в січні 1270 року прийняв титул герцога Каринтії й володаря Крайни та Віндицької марки [20, s.204; 24, s.125]. Натомість Філіпп Шпангаймський у боротьбі за владу над Каринтією кинувся шукати підтримки в особі сина й співправителя угорського монарха Бели IV, молодшого короля (з 1262 р.) Іштвана V [15, p. 510].

На початку лютого 1270 року чеський правитель скликав до Відня низку світських можновладців та церковних ієрархів.До Відня, зокрема, прибуло кілька графів на чолі з братами Альбертом II і Менгартом ГройчеТирольськими, а також єпископи Бріксена, Бамберга, Фрейзінгена, Пассау, Гурка й Оломоуца. Присутність таких поважних представників світської знаті та кліру свідчила про авторитет чеського монарха за межами власного королівства, який за їх участі намагався вирішити дві проблеми. По-перше, Пршемисл Отакар II прагнув посприяти Фрідріхові з роду Веттінів, який був нареченим його доньки, зійти на німецький трон. Інтереси Веттінівпри цьому репрезентувала група графів із центральних регіонів Німеччини на чолі 3 Оттоном фон Орламюнде, для яких сходження Фрідріха на трон відкривало нові можливості. По-друге, чеський король хотів якнайшвидше врегулювати суперечку з Філіппом Шпангаймським за Каринтію й утвердити свою владу у Крайні. Під час перебування у Відні єпископи Бруно Бріксенський і Конрад Фрейзінгенський визнали сюзеренітет Пршемисла Отакара II над своїми маєтками в Каринтії та Крайні [12, num, 284 - 285, p.309 - 311; 13, num. 603, p.199 - 201, num.605, p.202 - 203; 24, s.127; 26, s.144], а отже - і легітимність його прав на успадкування цих герцогств. Крім того, вчинок згаданих єпископів був відповіддю на дії Філіппа Шпангаймського, який спричинив дестабілізацію в регіоні.

Очевидно, Пршемисл Отакар II іменував у Відні й нових високопосадовців для управління Штирією та Каринтією. Так, капітаном Штирії став чеський маршалок, бургграф звиковський Пуркарт з Яновиць (zvikovský purkrabi Purkart z Janovic). Натомість капітаном Каринтії було призначено графа Ульріха фон Гайнбурга, який, за збігом обставин, був єдиним представником місцевої знаті, присутнім при підписанні угоди в Подєбрадах. Чеський король одружив його із каринтійською герцогинею 
Агнес (донькою Гертруди Бабенберг), вдовою покійного Ульріха III Шпангаймського. Нове подружжя не становило для Пршемисла Отакара II конкуренції в Каринтії, а навпаки - могло стати противагою Філіппові Шпангаймському. Граф Ульріх фон Гайнбург отримав від Пршемисла Отакара II нові маєтки,тож за сприятливих обставин його рід з часом міг сподіватися навіть на отримання влади герцога [24, s.128].

Після цього розпочалася підготовка широкомасштабної акції проти Філіппа Шпангаймського. Перш за все, чеська дипломатія спричинилася до того, що в серйозній небезпеці опинилися володіння Філіппа Шпангаймського в Італії. Йдеться про союзну угоду, яку 1 травня 1270 p. уклали в Чівідале каноніки Аквілейського патріархату й фріульська знать (canoniciecclesiaeAquileginensisnecnonlaiciterraeForiJulii) у союзі 3 Пршемислом Отакаром II [19, num.21; 24, s.128].

Як відомо, прагнення Філіппа Шпангаймського здобути Каринтію активно підтримав молодший угорський король ІштванV, який після смерті 3 травня 1270 р. Бели IVстав одноосібним володарем країни. В останні роки свого правління Бела IV, очевидно, обмірковував питання доцільності того, аби угорський трон успадкував саме ІштванV. Однак після того, як 1269 р. раптово помер його другий син - Бела молодший, протидіяти цьому не було сенсу.

Про важке становище Бели IV та його найближчого оточення свідчить i лист, який він надіслав чеському королю. У ньому Бела IV просив Пршемисла Отакара II, аби той прихистив його дружину, доньок і всіх “наших баронів, які залишилися вірними”. Попри те, що лист є формуляром i має незвичну структуру, в його вірогідності, на думку Й.Жемлічки, не доводиться сумніватися, головним чином через подальші події. Річ у тому, що невдовзі після смерті Бели IVдо Чехії прибула перша хвиля угорської еміграції на чолі з його донькою Анною, матір'ю Пршемислової дружини Кунігунди. Вона привезла до Праги частину угорських коронаційних регалій [26, s.146].

Такий поворот подій серйозно підривав позиції Іштвана V.Крім того, ІштванVне погоджувався 3 претензіями чеського правителя на Каринтію i Крайну, адже формально Угорщина також мала спадкові права на ці землі. На законність Пршемислових прав на Каринтію і Крайну кинула тінь і та обставина, що Ульріхова вдова Агнеса свою спадщину заповіла угорському королеві, котрий доводився ій родичем [18, s.47 - 48]. Таким чином, визрівала чергова сутичка Пршемисла Отакара II 3 Арпадовичами за альпійські території.

Задля протидії Пршемислові Отакарові II амбітний Іштван V (1270 1272) навіть відновив античеську коаліцію у складі Угорщини, Баварії й Малопольщі (Краківщини). У цій ситуації Пршемисл Отакар II прибув у травні 1270 року до Знойма, аби зайнятися організацією захисту кордонів 
свого королівства.Та позаяк від Іштвана V надійшла пропозиція зустрітися та врегулювати суперечку мирним шляхом, то військові операції не набули значного розмаху.

Ворогуючі сторони досягли компромісу у Брні, де 6 липня 1270 p. було домовлено про погодження до дня св. Гавла (16 жовтня) умов примирення та про зустріч двох королів біля Пожоні (Братислави). При цьому Пршемислові Отакарові II довелося визнати факт перебування Філіппа Шпангаймського на боці Угорщини, що підсилило надії останнього на успіх. На перемовини чеський володар прибув у супроводі численної шляхти зі своїх земель, нового зальцбурзького архієпископа Фрідріха фон Вальхена, а також єпископів Пассау, Бамберга, Фрейзінгена і Зеккау. Разом зі своєюсвитою він зупинився в Гайнбурзі [20, s.215 - 217; 24, s.130].

Очевидно, 16 жовтня 1270 р. два монархи, Пршемисл Отакар II та Іштван V, зустрілися на острівці посеред Дунаю між містами Пожонь i Потендорф, куди їх з невеликим супроводом доправили на човнах. Одним із основних джерел про цю подію є хроніка Отокара Штирійського. Ї̈̈ автор, зокрема, пише про недовіру, що панувала між обома королями, про непідготовленість дипломатів Іштвана $\mathrm{V}$, а також вказує на улесливий характер мирних переговорів. Чеський і угорський правителі дійшли згоди про продовження перемир'я до Дня св. Мартина (11 листопада), а відтак - ще на два роки. Позаяк Філіпп Шпангаймський порушив перемовини нападом на італійське місто Порденоне, сюзереном якого був Пршемисл Отакар II, a отже, вийшов 3 переговорного процесу, то Іштван Vприпинив бути гарантом його інтересів [11, num.39, p. 41; 16, v.10325 - 10445, p.136 - 138; 20, s.217; 26 , s.147-148].

Чеський король використав перемир'я, щоб перебрати владу в Каринтії та Крайні, а відтак негайно вирушив на південь. 3 фрагментарних i подекуди суперечливих свідчень довідуємося, що вже в листопаді 1270 р. військо Пршемисла Отакара II зайняло Любляну. Це місто було опорним пунктом Філіппа Шпангаймського, якому тепер довелося змиритися 3 реальністю й задовольнитися визначеними прибутками. Представники знаті (Вільям фон Шарфенберг, Миколай фон Ловенберг), які чинили спротив чеському володареві, кинулися шукати прихисток в Угорщині. Серед дослідників немає одностайності 3 приводу того, чи було проведено символічний ритуал посаження Пршемисла Отакара II на кам'яний трон каринтійських герцогів. Так, В.Ванічек вважає, що ця подія мала місце, тоді як Й.Жемлічка не дає ствердної відповіді на це питання [24, s.131; 26, s. 147 148]. Так чи інакше, але наприкінці 1270 р. Пршемисл Отакар II утвердив своє панування над Каринтією і Крайною.

Узагальнюючи викладений матеріал, можемо зробити такі висновки. Наприкінці 60-х років XIII ст. чеський король Пршемисл Отакар II став претендувати на герцогство Каринтію, де володарював його бездітний кузен 
Ульріх III Шпангаймський. Він був також герцогом Крайни, владу над якою отримав завдяки шлюбу з єдиною спадкоємицею цього територіального князівства.У грудні 1268 року Ульріх III Шпангаймський підписав у м.Подєбради угоду, згідно з якою передавав Пршемислові Отакарові II всі спадкові права на свої володіння. Таке рішення суперечило намірам Ульріхового брата Філіппа, який теж висував претензії на Каринтію і Крайну. В якості компенсації Філіпп отримав в управління Аквілейський патріархат. Та коли після смерті Ульріха III в Каринтію було призначено королівського капітана, то Філіпп не бажав 3 цим миритися й робив усе задля встановлення тут своєї влади. Щоправда, він не розрахував власні сили і врешті-решт наприкінці 1270 р. Пршемисл Отакар II досягнув мети й заволодів Каринтією і Крайною.

\section{Список використаних джерел}

1. Брокгауз. Історія Німеччини у світлинах / пер. з нім. К. : Юніверс, 2010. 568 с. (серія “Історична думка").

2. Вис Э.В. Фридрих II Гогенштауфен / [пер. с нем. Е.Б.Каргиной]. М.: АСТ : Транзиткнига, 2005. 378 с. (Историческая библиотека).

3. Глогер Б. Император, Бог и дьявол. Фридрих II Гогенштауфен в истории и легенде / [пер. с нем. А.Беленькой]. СПб. : Евразия, 2003. 288 с.

4. История Словении / Л.А.Кирилина, Н.С.Палько, И.В.Чуркина; отв. ред. И.В.Чуркина. СПб: Алетейя, 2011. 480 с.

5. Лампрехт К. Исторія германскаго народа / [пер. с нъмецкаго П.Николаева]. М.: Типо-литографія В. Рихтеръ, 1895. Томъ второй. Части III и IV. $656 \mathrm{c.}$

6. Ліхтей I. Універсалістські тенденції в зовнішній політиці чеського короля Пршемисла Отакара II (1253-1278) // Науковий вісник Ужгородського університету. Серія: Історія. Ужгород : Видавництво Валерія Падяка, 2000. Вип. 5: До 55-річчя заснування Ужгородського державного університету та історичного факультету. С.67-75.

7. Семёнов И.С. Христианские династии Европы. Династии, сохранившие статус владетельных. Генеалогический справочник. М.: ОЛМА-ПРЕСС, 2002. $494 \mathrm{c}$.

8. Цьольнер Е. Історія Австрії / пер. 3 нім.Роман Дубасевич, Христина Назаркевич, Анатолій Онишко, Наталя Іванчук. Львів : Літопис, 2001. $712 \mathrm{c}$.

9. Annales Sancti Rudperti Salisburgenses a. 1 - 1286 (Tab.V) / Ed. W. Wattenbach // Monumenta Germaniae Historica. Scriptorum / Edidit Georgius Henricus Pertz. Hannoverae : Impensis bibliopolii avlici Hahniani, MDCCCLI [1851]. Tomus IX. P. $758-810$.

10. Anonymi chronicon Bavaricum Ab A.C.1253. ad. A.C.1518.// Rerum Boicarum Scriptores: Nusquam Antehac Editi Quibus Vicinarum Quoque 
Gentium nec non Germaniae universae Historiae Ex Monumentis Genuinis Historicis Et Diplomaticis Plurimum Illustrantur. Tomus I. / Ex Membranis \& Chartis vetustis collegit, descripsit ac Monitis praeviis indiceque copioissimo instruxit atque edidit Andreas Felix Oefelius Monacensis, Augustae Vindelicorum, 1763. - p. 388 - 391;

11. Codex diplomaticus Arpadianus continuatus=Árpádkori új okmánytár. 12. köt. / megbizásából közzé teszi Wenzel Gusztáv. Budapest : Eggenberger, 1874. 707 p.

12. Codex diplomaticus Austriaco-Frisingensis: Sammlung von Urkunden und Urbaren zur Geschichte der ehemals freisingischen Besitzungen in Österreich / hrsg. J. Zahn (Fontes rerum Austriacarum. 2. Abt., Diplomataria et acta; Bd. 31). Wien: Kaiserlich-königliche Hof- und Staatsdruckerei, 1870. 469 p.

13. Codex diplomaticus et epistolaris Regni Bohemiae. - Praha : Academia, 1981. - Tomi V, fasciculis secundus, Inde ab a. MCCLXVII ad a. MCCLXXVIII / condidit Gustavus Friedrich ; ediderunt Jindřich Šebánek et Sáša Dušková. $-621 \mathrm{p}$.

14. Continuatio Garstensis a. 1182 - 1257. / Ed. W. Wattenbach // Monumenta Germaniae Historica. Scriptorum / Edidit Georgius Henricus Pertz. Hannoverae : Impensis bibliopolii avlici Hahniani, MDCCCLI [1851]. Tomus IX. P. 593-600.

15. Continuatio Mellicensis a. 1124-1564. / Ed. W. Wattenbach // Monumenta Germaniae Historica. Scriptorum / Edidit Georgius Henricus Pertz. Hannoverae : Impensis bibliopolii avlici Hahniani, MDCCCLI [1851]. Tomus IX. P. 501-535.

16. Deutsche Chroniken und andere Geschichtsbücher des Mittelalters / Nach den Abschriften Franz Lichtensteins ; herausgyeben von Joseph Seemüller. Hannover : Hahnsche Buchhandlung, MDCCCLXXXX (1890). Tomus V. Pars I. Ottokars Österreichische Reimchronik. 720 p. (Monumenta Germaniae Historica. Scriptorum qui vernacula lingua usi sunt ; T. 5, P. 1).

17. Historia annorum 1264-1279. // Monumenta Germaniae Historica. Scriptorum / Edidit Georgius Henricus Pertz. Hannoverae : Impensis bibliopolii avlici Hahniani, MDCCCLI [1851]. Tomus IX. P. $649-654$.

18. Marsina R. Přemysl Otakar II. a Uhorsko / Richard Marsina // Folia Historica Bohemica 1/ ved. red. Josef Žemlička. Praha : Ústav československých a světových dějin ČSAV, 1979. Praha, 1979. S. $37-65$.

19. Monumenta historica ducatus Carinthiae. Funfter Band. Die Karntner Geschichtsquellen 1269 - 1286. Herausgegeben von Hermann Wiessner. Klagenfurt: Verlag des Geschichtsvereines für Kärnten, 1956. 511 p.

20. Novotný V. České dějiny. Dilu I. Část 4. Rozmach české moci za Přemysla II. Otakara (1253-1271) / Václav Novotný. Praha : Nákladem Jana Laichtera, 1937. 499 s. (Laichterův výbor nejlepších spisů poučných ; kniha LXI.). 
21. Ogris A. Vztah Přemysla Otakara II. ke korutanskému vévodství na pozadí politického vývoje ve 13. století /Alfred Ogris //Česko-rakouské vztahy ve 13. století : Rakousko (včetně Štýrska, Korutan a Kraňska) v projektu velké říše Přemysla Otakara II. : sborník př́spěvků ze symposia konaného 26.-27. září 1996 ve Znojmě. - Praha : Rakouský kulturní institut : Filozofická fakulta Univerzity Karlovy, 1998. - S. $65-66$.

22. Přehled dějin Československa. I/1. Do roku 1526 / Hlavní redakce Jaroslav Purš, Miroslav Kropilák. - Praha : Academia, 1980. - 645 s.

23. Riedmann J. Hrabata z Tyrol-Gorice a Přemysl Otakar II. - vliv českého krále v severovýchodní Itálii /Josef Riedmann// Česko-rakouské vztahy ve 13. století : Rakousko (včetně Štýrska, Korutan a Kraňska) v projektu velké ř́šse Přemysla Otakara II. : sborník př́spěvků ze symposia konaného 26.-27. září 1996 ve Znojmě. - Praha : Rakouský kulturní institut : Filozofická fakulta Univerzity Karlovy, 1998. - S. 131-143.

24. Vaníček V. Velké dějíny zemi Koruny české. Svazek III., 1250-1310 / Vratislav Vaníček. - Praha-Litomyšl : Paseka, 2002. -760 s.

25. Vaníček V. "Otakarovská" středovýchodní Evropa a říšské interregnum (1245/50-1273) / Vratislav Vaníček // Pocta králi : k 730. výročí smrti českého krále, rakouského vévody a moravského markraběte Přemysla Otakara II. / Libor Jan, Jiř́ Kacetl a kolektiv. - Brno ; Znojmo : Matice moravská pro projekt Pocta králi železnému a zlatému 2008 : Výzkumné středisko pro dějiny střední Evropy: prameny, země, kultura, 2010. - S.15 - 45.

26. Žemlička J. Přemysl Otakar II. Král na rozhraní věků / Josef Žemlička. - Praha : Lidové noviny, 2011. - 752 s. - (Edice Česká historia, sv.25).

\section{REFERENCES}

1. Annales Sancti Rudperti Salisburgenses a. 1 - 1286 (Tab.V). Wattenbach,W. (Ed.). (1851).In: Monumenta Germaniae Historica. Scriptorum.Georgius Henricus Pertz (Ed). Hannoverae : Impensis bibliopolii avlici Hahniani. Tomus IX, p. $758-810$.

2. Anonymi chronicon Bavaricum Ab A.C.1253. ad. A.C.1518. (1763). In: Rerum Boicarum Scriptores: Nusquam Antehac Editi Quibus Vicinarum Quoque Gentium nec non Germaniae universae Historiae Ex Monumentis Genuinis Historicis Et Diplomaticis Plurimum Illustrantur. Tomus I. Ex Membranis \& Chartis vetustis collegit, descripsit ac Monitis praeviis indiceque copioissimo instruxit atque edidit Andreas Felix Oefelius Monacensis - Augustae Vindelicorum: Sumptibus Ignatii Adami \& Francisci Antonii Veith Bibliopolarum, p. $388-391$.

3. Brokgauz. (2010) Istoriya Nimechchy'ny'u svitly`nax. Per. z nim. Kyiv: Yunivers, $568 \mathrm{p}$.

4. Codex diplomaticus Austriaco-Frisingensis: Sammlung von Urkunden und Urbaren zur Geschichte der ehemals freisingischen Besitzungen in Österreich 
(1870). Zahn, J. (Ed.)In : Fontes rerum Austriacarum. 2. Abt., Diplomataria et acta; Bd. 31. Wien: Kaiserlich-königliche Hof- und Staatsdruckerei, 469 p.

5. Continuatio Garstensis a. 1182 - 1257. Wattenbach,W. (Ed.). (1851).In: Monumenta Germaniae Historica. Scriptorum.Georgius Henricus Pertz (Ed). Hannoverae : Impensis bibliopolii avlici Hahniani. Tomus IX,p. 593-600.

6. Continuatio Mellicensis a. 1124-1564. Wattenbach,W. (Ed.). (1851).Monumenta Germaniae Historica. Scriptorum.Georgius Henricus Pertz (Ed). Hannoverae : Impensis bibliopolii avlici Hahniani. Tomus IX, p. 501-535.

7. Cz`ol’ner, E. (2001).Istoriya Avstriyi, L`viv,712 p.

8. Deutsche Chroniken und andere Geschichtsbücher des Mittelalters (1890). Nach den Abschriften Franz Lichtensteins; herausgyeben von Joseph Seemüller. In: Monumenta Germaniae Historica. Scriptorum qui vernacula lingua usi sunt.Tomus V. Pars I. Ottokars Österreichische Reimchronik. Hannover: Hahnsche Buchhandlung, 720 p.

9. Gloger B.(2003). Imperator, Bog i d'javol. Fridrih II Gogenshtaufen v istorii i legende, per. s nem. A.Belen'koj. SPb.: Evrazija, $288 \mathrm{~s}$.

10. Gusztáv, W (Ed.). (1874). Codex diplomaticus Arpadianus continuatus = Árpádkori új okmánytár, 12. köt. Budapest : Eggenberger, $707 \mathrm{~s}$.

11. Historia annorum 1264-1279.(1851).In: Monumenta Germaniae Historica. Scriptorum.Georgius Henricus Pertz (Ed). Hannoverae : Impensis bibliopolii avlici Hahniani. Tomus IX, p. $649-654$.

12. Kirilina, L.A., Pal'ko,N.S., Churkina I.V. (2011). Istoriya Slovenii. $\mathrm{SPb}$ : Aletejya, $480 \mathrm{p}$.

13. Lampreht,K. (1895). Istorijagermanskagonaroda; per. snemeckagoP.Nikolaeva. M.: Tipo-litografijaV. Rihter. Tomvtoroj. Chasti III iIV. $656 \mathrm{p}$.

14. Lixtej,I.(2000).

Universalists ‘kitendenciyivzovnishnijpolity`ciches `kogokorolyaPrshemy`slaOtakar aII (1253-1278). Naukovy jvisny'kUzhgorods kogouniversy'tetu. Seriya: Istoriya.Uzhgorod: Vy'davny'cztvoValeriyaPadyaka, Vol. 5: Do 55richchyazasnuvannyaUzhgorods 'kogoderzhavnogouniversy` tetutaistory`chnogofak ul'tetu, p.67-75.

15. Marsina,R.

(1979).PřemyslOtakarII.

aUhorsko.In. FoliaHistoricaBohemica 1.Josef Žemlička (Ed). Praha : Ústav československýchasvětovýchdějin ČSAV, p. 37 - 65 .

16. MonumentahistoricaducatusCarinthiae. DieKarntnerGeschichtsquellen 1269 - 1286. - Herausgegebenvon HermannWiessner. Klagenfurt: Verlag des Geschichtsvereines für Kärnten, 1956. $-511 \mathrm{p}$.

17. Novotný, V. (1937).České dějiny. Dilu I. Část 4. Rozmach české moci za Přemysla II. Otakara (1253 - 1271). Praha : Nákladem Jana Laichtera, 499 s. (Laichterův výbor nejlepších spisů poučných ; kniha LXI.). 
18. Ogris, A. (1998).Vztah Přemysla Otakara II. ke korutanskému vévodství na pozadí politického vývoje ve 13. století. In: Česko-rakouské vztahy ve 13. století : Rakousko (včetně Štýrska, Korutan a Kraňska) v projektu velké říše Přemysla Otakara II. : sborník příspěvků ze symposia konaného 26.-27. záríi 1996 ve Znojmě. Praha : Rakouský kulturní institut : Filozofická fakulta Univerzity Karlovy, p. 65-66.

19. Purš, J., Kropilák, M. (Ed). (1980).Přehled dějin Československa. I/1. Do roku 1526. Praha: Academia, 1980, 645 p.

20. Riedmann, J. (1998), Hrabata z Tyrol-Gorice a Přemysl Otakar II. vliv českého krále v severovýchodní Itálii. In: Česko-rakouské vztahy ve 13. století : Rakousko (včetně Štýrska, Korutan a Kraňska) v projektu velké řǐše Přemysla Otakara II. : sborník př́spěvků ze symposia konaného 26.-27. záŕí 1996 ve Znojmě. Praha : Rakouský kulturní institut : Filozofická fakulta Univerzity Karlovy, p. 131-143.

21. Semjonov, I. S. (2002).Hristianskie dinastii Evropy. Dinastii, sohranivshie status vladetel'nyh. Genealogicheskij spravochnik. Nauch. red. E. I. Kuksina. Predisl. O. N. Naumov. M.: OLMA-PRESS, 494 p.

22. Šebánek, J., Dušková S. (Ed.) (1981). Codex diplomaticus et epistolaris Regni Bohemiae. Praha : Academia. Tomi V, fasciculis secundus, Inde ab a. MCCLXVII ad a. MCCLXXVIII; condidit Gustavus Friedrich, 621 p.

23. Vaníček, V. (2002). Velké dějíny zemi Koruny české. SvazekIII., 1250-1310.Praha-Litomyšl: Paseka. 760 p.

24. Vaníček, V. (2010).“Otakarovská” středovýchodní Evropa a ř́šské interregnum (1245/50-1273). In: Poctakráli: k 730. výroči smrti českéhokrále, rakouskéhovévodyamoravskéhomarkrabětePřemyslaOtakaraII. LiborJan, Jiři Kacetlakolektiv. Brno; Znojmo: Maticemoravská proprojektPoctakráli železnémuazlatému 2008: Výzkumné střediskoprodějinystřední Evropy: prameny, země, kultura, p. $15-45$.

25. Vis,Je.V. (2005). Fridrih II Gogenshtaufen; per. snem. E.B.Karginoj. M.:AST: Tranzitkniga, $378 \mathrm{p}$.

26. Žemlička, J.(2011).Přemysl OtakarII. Králnarozhraní věkư. Praha: Lidové noviny, 752 p. (Edice Česká historia, sv.25). 